\title{
O SUPERENDIVIDAMENTO NO ORDENAMENTO JURÍDICO BRASILEIRO
}

\section{Clayrtha Raissa Nascimento Gonçalves ${ }^{1}$ Paulo Sérgio Velten Pereira ${ }^{2}$}

\begin{abstract}
RESUMO: Estuda-se a lógica do pensamento sistemático e o direito civil constitucional para se visualizar o reconhecimento da questão do superendividamento pelo ordenamento jurídico. Metodologicamente, por abordagem dedutiva, analisa-se o Superendividamento como condição do consumidor de boa-fé. O Projeto de Lei 3515/2015 prevê tratamento ao superendividamento. Conclui-se que, a partir da autonomia privada em consonância com a os direitos fundamentais, situa o reconhecimento do superendividamento no ordenamento jurídico, diante da ordem e unicidade do sistema, sendo pertinente a possibilidade de tratamento do superendividamento de boa-fé.
\end{abstract}

Palavras-chave: Ordenamento jurídico; Pensamento sistemático; Direito civil constitucional; Superendividamento; Consumidor.

\section{OVERENDIVIDAMENTO IN THE BRAZILIAN LEGAL ORDER}

ABSTRACT: The logic of systematic thinking and constitutional civil law are studied in order to visualize the recognition of the issue of over-indebtedness by the legal system. Methodologically, through a deductive approach, over-indebtedness is analyzed as a condition of the consumer in good faith. Bill 3515/2015 provides for treatment of over-indebtedness. We conclude that, based on private autonomy in line with fundamental rights, there is the recognition of over-indebtedness in the legal system, given the order and uniqueness of the system, with the possibility of treating over-indebtedness in good faith being pertinent.

Keywords: Legal order; Systematic thinking; Constitutional civil law; Over-indebtedness; Consumer.

\section{INTRODUÇÃO}

A temática do superendividamento merece espaço no campo das pesquisas, inclusive em cenários de crise financeiras como em que a nação passa na atualidade. Por sua vez, o presente artigo pretende abordar onde se situa no ordenamento jurídico o reconhecimento e o tratamento da situação de superendividamento.

\footnotetext{
${ }^{1}$ Mestranda do Programa de Pós Graduação em Direito e Instituições do Sistema de Justiça da Universidade Federal do Maranhão - UFMA. Especialista em Direito do Trabalho e Processo do Trabalho (Damásio). Advogada. Endereço postal: Av. General Arthur Carvalho, $n^{\circ}$ 132, Residencial Turu, Paço do Lumiar/MA. Endereço eletrônico: clayrtharaissa@yahoo.com.br

${ }^{2}$ Mestre e Doutor em Direito pela Pontifícia Universidade Católica de São Paulo - PUC/SP. Professor adjunto da Universidade Federal do Maranhão - UFMA. Desembargador do Tribunal de Justiça do Estado do Maranhão TJMA. Endereço postal: TJMA, Av. Dom Pedro II, s/nº, Centro, São Luís/ MA. Endereço eletrônico: paulovelten@uol.com.br.
} 
A relevância cientifica da pesquisa encontra-se no chamado Projeto de Lei do Superendividamento, o tratamento por institutos parecidos em outros ordenamentos como o francês, de dados que mostram a situação de superendividamento das famílias, entre outros.

No presente artigo, a abordagem metodológica é dedutiva, baseada em pesquisas bibliográficas. Partindo da premissa maior que é o sistema jurídico para se chegar na abordagem do reconhecimento da importância de situar o superendividamento no ordenamento jurídico.

Para tanto, o desenvolvimento do artigo se divide em três momentos. No primeiro momento, como ponto de partida, descortina-se a lógica do pensamento sistemático e o lugar do direito civil no ordenamento jurídico entendendo os requisitos de ordem e unidade para concreção de um sistema jurídico. Ressaltando a mobilidade do direito civil em consonância com a ordem constitucional, importantes aspectos para se adentar no tema do superendividamento.

O segundo capítulo insere a concepção e a questão da compatibilidade do reconhecimento do superendividamento para o ordenamento jurídico, ressalta-se a ausência de previsão normativa específica, observando seu alcance na mobilidade do sistema, na função social do contrato, na boa-fé objetiva e nos direitos fundamentais.

Por fim, o capítulo último aborda a relevância do tratamento ao superendividamento, posto a análise de sua compatibilidade com o sistema, como proposta de resgate à vida civil enquanto consumidor. Para isso, importa que a autonomia da vontade seja respeitada como forma de defesa dos contratos e que o tratamento seja voltado aos superendividados de boa-fé, a fim de construir modelos jurídicos centrados no viés constitucional sem desvencilhar-se do caráter privado do direito.

\section{A LÓgICA DO PENSAMENTO SISTEMÁtico E O DIREITO CIVIL CONSTITUCIONAL}

A ideia de sistema remonta ao conceito de um conjunto de elementos interligados e contornados de completude. O pensamento sistemático do sistema jurídico parte do mesmo viés, que leva em conta um todo de caráter único e organizado. E esse todo não é imóvel, antes porém dinâmico. 
O Direito convive com a dinâmica e mutações da sociedade, posto que as alterações sociais significam mudança do homem. De forma latente é possível observar com as desigualdades de antes do Estado liberal (liberdade, igualdade, fraternidade), o que, com a ascensão da autonomia privada acarretou a crescente preocupação do Estado para com os administrados. De fato, com a crescente transformação da relação entre Estado e Particular, observa-se a proeminência do Estado de Direito (POPP, 1999).

Desse modo, a imobilidade do direito civil não é aceitável, inclusive com o novo ângulo de visão oriundo do direito civil constitucional que insere a pessoa humana no centro do ordenamento e das relações jurídicas, destacando a função social do contrato, a boa-fé, a liberdade contratual e o enriquecimento sem causa. Ou seja, a conformidade do mundo moderno ao direito civil, reflete diretamente da transição ocorrida da autonomia da vontade para a autonomia privada (NANNI, 2004).

Logo, esse sistema encontra balizas na Constituição Federal. São comandos para a atuação do legislador e limites do intérprete. Nesse sentido Popp (1999, p. 157):

\footnotetext{
Logo, as regras constitucionais operam-se por ação ou omissão e mesmo as de caráter programático servem de comando ao legislador impeditivo da edição de lei de significado diverso ao preconizado na Carta Magna ou mesmo pela cessação da eficácia de regras eminentemente contrários ao lá estabelecido.
}

No entanto, não significa que o âmbito privado perdeu sua liberdade fruto dos princípios clássicos que encontra limites nos princípios modernos do Direito privado, em especial dos contratos. Entre esses últimos, tem-se a dignidade da pessoa humana. Desse modo, enaltecendo o contexto constitucional de um olhar voltado ao particular como reflexo dos anseios da sociedade enquanto relações sociais entre esses ou entre esses e o Poder Público, tendo como relevância a dignidade humana. Nesse sentido, ressalta-se: "Percebe-se então uma tendência mundial de centralização do ordenamento jurídico por inteiro da ordem constitucional. Tal aspecto, aliado ao intervencionismo estatal no âmbito privado e a chamada privatização do direito público, retirou a relevância da distinção.” (POPP, 1999, p. 161).

Além da observância do perfil funcional da norma ordinária, assim como sua releitura em harmonia com os princípios fundamentais, é pertinente abordar sua relevância nas relações de direito civil. Para Tepedino, "trata-se de um processo cognitivo unitário voltado a individuar a norma a ser aplicada" (2004, p. 579), não apenas como sua função 
interpretativa, mas no direito substancial que expressa, em sua essência, para as relações interindividuais.

O outrora limite negativo da Constituição, baseado em regras de limitação de poder do Estado, passando pela distinção na aplicação do direito público e do direito privado, transformou-se em regras soberanas de viés não só negativo, mas positivo, também. $\mathrm{O}$ percurso histórico trouxe alterações significativas quanto a referida distinção, não mais aceitável diante da regra de conduta exigida de todos, incluindo os Poderes, negando a exigência de aplicações diversas quando se tratar de pessoas jurídicas de direito público. Ainda mais latentes, diante do pensamento oriundo da Segunda Guerra Mundial, preconizado pelo caráter humanístico de direitos fundamentais a serem assegurados, em relação aos países que reconheceram o cidadão como ser de direitos (POPP, 1999).

O caráter de unidade do sistema jurídico, além do centralismo constitucional, é demonstrado pelos princípios constitucionais que constituem o ordenamento jurídico dando forma e unidade. Devendo essa unidade ser conciliada com a pluralidade de ordens normativas parciais, diante da sua dinâmica que acarreta mobilidade e plasticidade normativa (TEPEDINO, 2004).

Em relação às qualidades da ordem e da unidade, como características do conceito geral de sistema, é importante frisar que assim como Kant designou o sistema como a unidade sob uma ideia, de conhecimentos variados ou como um conjunto de conhecimentos ordenados, outros filósofos conceituaram de formas semelhantes com duas características a comparecer: a ideia de ordenação e da unidade, de forma interligadas, conforme acentua Canaris (2008). Onde a ordenação como "um estado de coisas intrínseco racionalmente apreensível, isto é, fundado na realidade" e a unidade "modifica o que resulta já da ordenação, por não permitir uma dispersão numa multitude de singularidades desconexas." (CANARIS, 2008, p. 12-13).

Assim, são dois vieses do sistema, um o sistema de conhecimentos (sistema externo) e o outro dos objetos do conhecimento (sistema interno), devendo aquele ser o correspondente desse como forma de, cientificamente, confirmar o objeto (que é o direito) do conhecimento.

No entanto, ao se tratar da adequação e unidade como emanações e postulados da ideia de Direito, a ordem interior e a unidade pertencem às mais fundamentais exigências ético-jurídicas e firmam-se na própria ideia de Direito. As exigências de ordem, tanto para o 
legislador quanto ao juiz, decorrem da premissa de justiça por razões materiais, portanto devem ser com adequação valorativa (CANARIS, 2008).

Quanto à unidade, sua caracterização no Direito conduz ao princípio da igualdade e a realização da tendência generalizadora da justiça (em oposição à tendência individualizadora), assim vislumbrando aspectos gerais em detrimento dos do caso concreto. Desse modo, "a ordem do Direito não se dispersa numa multiplicidade de valores singulares desconexos." (CANARIS, 2008, p. 21).

Portanto, posto a ordem e unidade do sistema, o direito civil sofre influência direta da ordem constitucional, "Esta releitura do sistema jurídico, evidentemente, passa por uma clara interpretação do princípio da dignidade da pessoa humana e de sua aplicação às demais searas do Direito Civil." (POPP, 1999, p. 152).

Daí se depreende que, ao adentrar no protagonismo do homem, a inauguração da nova Carta Magna trouxe a releitura de todo ordenamento jurídico, posto a latência de novas interpretações. Assim, depreende-se que a Constituição Federal encabeça o Direito Pátrio que dá ao homem a autoria do mundo da vida como parte de sua dignidade humana.

Resguardando o entendimento acima ao negócio jurídico, frisa-se a importância da interpretação pelo intérprete autêntico para garantia dos direitos privados e observância de sua função social. Assim, partindo da unidade do ordenamento jurídico, a relação entre o contrato e sua fonte no poder negocial, considerando o pressuposto de que a correta interpretação das declarações de vontade atravessam o sentido literal, o contexto verbal e o contexto situacional, busca-se a interpretação restritiva e conservativa do negócio na projeção de modelos jurídicos decisórios baseados nos modelos legais e dogmáticos (PEREIRA, 2008). ${ }^{3}$

De certo que, para tanto, a hermenêutica possui destaque na tarefa de se encontrar os limites e alcance do poder negocial. Assim, a ciência hermenêutica busca os fins do direito, nessa perspectiva os princípios constitucionais e civis possuem grande relevo no ordenamento jurídico. Conciliar, harmonizar o alcance das normas constitucionais com os princípios fundamentais de direito privado (posto que estes são conformes a Constituição) deverá ser feito através de uma interpretação sistemática. Popp (1999) cita Alexy para argumentar a

\footnotetext{
${ }^{3}$ Observa o autor que entender o conteúdo das fontes dos negócios jurídicos e aprimorar os modelos jurídicos decisórios condizente com o Estado Democrático de direito deve ser o objetivo do intérprete do Direito Privado. Assim, a solidariedade e a função social não são o fim do contrato, mas sim os fins econômicos de circulação de bens e riquezas.
} 
diferença qualitativa entre regras e princípios, esses como base do ordenamento e aquela de comando fático e jurídico.

Por esse ângulo, a pessoa humana como centro de ação do direito civil, concentra as relações jurídicas, tendo o direito privado como mecanismo primeiro de paz social, regulando o interesse das pessoas e disciplinando as suas responsabilidades à medida que se é eficaz. Desconsiderar as relações jurídicas é afastar da sociedade e do ser humano o exercício de inúmeros direitos fundamentais, separando assim, o Estado Social e o Estado de Direito, excluindo direitos individuais e da dignidade da pessoa humana, a existência do direito privado e da própria sociedade (POPP, 1999).

Como norma de valores elementares da pessoa humana, a Constituição passa a ter papel central no ordenamento jurídico posto a sua preocupação quanto às relações sociais. Lugar esse antes preenchido pelo Código Civil. Como lei maior, todos os atos e as normas infraconstitucionais em conformidade com ela devem estar, assim como oferece limites, devido a sua superioridade material e de fonte primária das normas. É a despatrimonialização do direito civil e, por outro viés, chamado de sua repersonalização, devido encontrar no bojo da Constituição os direitos fundamentais (FINGER, 2000).

Desse modo, a Constituição é considerada direta ou indiretamente na aplicação do ordenamento ao caso concreto. Portanto, o Direito Civil constitucional não é dissociado da Constituição, posto que essa é importante na hierarquia das fontes e na interpretação em conformidade diante da dinâmica do sistema jurídico aberto e de conteúdo prescritivo. (FINGER, 2000).

Portanto, como um todo organizado que é, a ordem do sistema jurídico é preconizada pelos direitos fundamentais aos quais o Direito Civil Constitucional acolhe em harmonia entre princípios constitucionais e civis sem perder o seu caráter privado necessário as relações negociais.

Nesse liame, quando se tratam dos valores da liberdade e da dignidade da pessoa humana “[...] é princípio geral do Direito e busca não só a dignidade coletiva [...], mas também pelo trato das indignidades individuais decorrentes de vínculos negociais em que prepondera a desigualdade, o descaso pelo direito alheio, o abuso do direito [...], etc." (POPP, 1999, p. 172).

Razão da existência da sociedade se resume na pessoa humana (personalismo ético) e a sua dignidade, principio esse fundamental, base para interpretação de todo ordenamento 
jurídico. Portanto, direito de ser considerado como ser de direitos e não ser lesado em sua existência (POPP, 1999).

Assim, é fim do Estado propiciar as condições para que todas as pessoas se tornem dignas, para isso utilizando seus meios para garantir a dignidade humana ao mesmo tempo limitando direitos que atentem contra a dignidade. No que diz respeito à liberdade contratual, essa é lesada quando desrespeitada a boa-fé (direito de informação, de honestidade, entre outros) e os demais direitos contratuais acessórios. Lembrado que o respeito à dignidade, pode ponderar sendo mitigado em face de situações gerais ou específicas de caráter extraordinário (POPP, 1999).

\section{O DIREITO CIVIL CONSTITUCIONAL E O RECONHECIMENTO DO SUPERENDIVIDAMENTO}

As alterações na visão do Direito civil pela ótica da Constituição, também foram expressivas nas relações de consumo, o que ressaltou o aspecto obrigacional sendo aproveitado pelo próprio direito civil e das obrigações. Passando o Código Civil a ser visto não mais como a constituição do direito privado, mas ocorrendo a socialização do direito privado, através de uma releitura à luz dos princípios constitucionais que requer a necessária obediência da ordem privada à Constituição (NANNI, 2004).

Desse modo, entender o conteúdo das fontes dos negócios jurídicos e aprimorar os modelos jurídicos decisórios condizentes com o Estado Democrático de direito deve ser o objetivo do intérprete do Direito Privado. Assim, a solidariedade e a função social não são o fim do contrato, mas sim os fins econômicos de circulação de bens e riquezas (PEREIRA, 2018). Alcançando o consumidor superendividado de boa-fé que almeja desvencilhar-se da trajetória de morte civil para o mercado de consumo.

Consumidor superendividado, possui conceito citado pela doutrina, em especial por Marques, Lima e Bertoncello (2010), que entende o superendividamento como a impossibilidade global do consumidor devedor-pessoa física e de boa-fé em pagar, com sua capacidade atual de renda e patrimônio, a totalidade de suas dívidas atuais e futuras de consumo em um tempo aceitável (MARQUES; LIMA; BERTONCELLO, 2010).

No entanto, estarmos em um Estado constitucional de direitos não pode significar o decreto de morte ou crise do contrato, ou seja, não retira dos pactos a sua vertente econômica 
oriunda do conteúdo de direito privado, mas aponta para sua remodelação através das novas formas de liberdade contratual inauguradas com a Constituição de 1988 que, inclusive, incluem outros microssistemas do Direito (PEREIRA, 2018).

Deve-se observar que o negócio jurídico é fonte normativa, no sentido de modo de manifestação de normas jurídicas. E é fonte sinônima de fonte de conhecimento e fonte de produção. Baseados no conceito lato de norma jurídica, norma é sinônimo de direito objetivo e de normas está formado o conteúdo do negócio jurídico (FERRI, 1969).

Se depreende dessa concepção, os elementos para noção jurídica da autonomia privada. Pois, os negócios jurídicos são a expressão da vontade dos indivíduos voltadas para a realização de interesses privados. Sendo a autonomia privada o querer da comunidade, e a vontade dessa é a vontade do Estado. Pela norma, ao indivíduo é dado o poder de criar direito, assim através da atividade negocial os sujeitos criam normas. (FERRI, 1969).

Outrossim, na ausência de norma ordinária de relação jurídica civil, a norma constitucional isoladamente pode ser fonte de disciplina, quando se reconhece nessa a supremacia em um ordenamento unitário. O que se destaca é a eficácia da norma constitucional no que diz respeito às relações pessoais e socioeconômicas, na presença ou não de uma normatização ordinária, dada a sua aptidão sobre situações subjetivas. Portanto, não havendo oposição do público e do privado, posto a unicidade do sistema normativo (TEPEDINO, 2004). Nesse sentido, “[...] não se trata de subordinar a norma constitucional às regras de inferior hierarquia, mas sim habilitar a constituição a surtir todos os seus efeitos jurídicos de maneira harmônica, clara e precisa.” (POPP, 1999, p. 164).

Ressaltando a relevância social que traz consigo a temática, conforme o Instituto Brasileiro de Defesa do Consumidor (IDEC, 2019), o superendividamento ocorre quando o endividado tem mais contas ou mais dívidas que a sua capacidade de pagamento e assim o mínimo existencial acaba comprometido, colocando milhões de brasileiros à margem do mercado consumidor, afetando as empresas, o comércio e principalmente a vida das famílias.

Esses superendividados, são 42 milhões de brasileiros em potencial de reaquecer a economia ao recuperar sua capacidade de consumo, injetando capitais no mercado sem recorrer a recursos estatais. Trata-se de uma questão social e um passo fundamental para diminuir o número de endividados e instituir o crédito responsável, reduzindo uma mazela que tem prejudicado milhões de brasileiros (IDEC, 2019). Por isso, um passo importante é o seu reconhecimento pelo sistema jurídico. 
É possível considerar que os modelos jurídicos negociais, cujos limites são encontrados nos modelos jurídicos legais e decisórios, são frutos dos objetivos do momento atual. Sempre em consonância com o Mundo da Vida, pois esse irá influenciar a dinâmica do Direito Privado. Assim, a interpretação deve estar pautada no sentido da fonte negocial, da norma (Modelos jurídicos legais), do momento histórico atual, de precedentes judiciais e orientação da doutrina (modelos jurídicos dogmáticos) a fim de que se chegue à integração normativa em consonância com o Estado democrático de direito e os fins do contrato de circulação de bens e riquezas, conforme firmado pelas partes. (PEREIRA, 2018).

Sobre a temática, destaca-se o tratamento francês (Code de la Consommation). Trata de modelo de reeducação financeira. A teoria francesa (modelo da recuperação pessoal), considera como superendividado o consumidor pessoa física de boa-fé que não consegue adimplir o conjunto de suas dívidas e busca saná-las num plano de pagamento, em até 5 anos, para grupos que preenchem alguns requisitos, inclusive, com a possibilidade do perdão dessa dívida. A teoria do Instituto do reste à vivre (mínimo/piso vital) busca o adimplemento das dívidas, mantendo o mínimo necessário à subsistência (CARVALHO, 2018, p. 369).

Para isso, importante observar que o sistema jurídico é móvel e a relevância de situar a situação de superendividamento no ordenamento. Canaris (2008) assevera que as características típicas de sistema quanto à unidade, é a unidade da pluralidade de contenção de normas singulares desconexas, mas através de poucos princípios constituintes que orientam as decisões singulares. Quanto à ordem, como pressuposto de existência da unidade, afirmando a existência de uma "ordem interior".

Deste modo, “[...] a visão de contrato não é mais aquela decorrente da ótica clássica, ou seja, também se amoldou a este novo enfoque social.” (POPP, 1999, p. 174). A liberdade econômica, enquanto espécie do gênero liberdade, é princípio fundamental que demonstra que deixou o Estado um modelo de puro liberalismo passando a um enfoque social com a ascensão da atenção para com a ordem social. Nesse sentido, a Justiça social e a busca pelo bem-estar de todos é compatível com a livre iniciativa (essa inclui de empresa e de contrato) (POPP, 1999).

A situação do consumidor superendividados em paralelo com a função social do contrato encontra guarita na ordem social, mas visando, ainda, o respeito ao pactuado como medida de observância da autonomia privada e os fins do contrato de circulação de bens e riquezas, importantes para o equilíbrio da economia. 
A passagem do liberalismo ao Estado social inaugurado com a atual Carta Constitucional, é a transição da vontade do contratante à busca do interesse social, visando a ordem social justa, posto que a livre concorrência é antagônica ao sistema de monopólio. Desse modo, a livre concorrência traz equilíbrio ao mercado uma vez que estimula a competitividade, inclusive com ganhos aos consumidores, proporcionado pela pluralidade de mercado (POPP, 1999).

$\mathrm{Na}$ ausência de um regramento especial para o tratamento do superendividamento, as cláusulas gerais poderão auxiliar para se encontrar soluções jurídicas. Martins-Costa (1999) entende que o enunciado de uma cláusula geral é não-apofântico, acarretando um outro formato de raciocínio do intérprete que buscará por critérios de aplicação. O primeiro critério para aplicação é detalhar a hipótese normativa e desenvolver soluções jurídicas onde, diante do caso concreto, o julgador recorre a elementos de outros espaços de dentro ou fora do sistema.

Já para o segundo critério de aplicação, a norma contida na cláusula geral reenvia a uma outra norma ou princípio do ordenamento jurídico ou para elementos extra- sistemáticos para fundamentar a interpretação. É a ressistematização destes elementos ao ordenamento jurídico. No entanto, esses dois critérios não são a totalidade do movimento intelectivo exigido para a concretização das cláusulas gerais (em sentido próprio). Mas há outras valorações legítimas a serem confrontadas (MARTINS-COSTA, 1999).

A condição de tratamento ao superendividamento perpassa da existência de boa-fé do indivíduo que não agiu com dolo, mas que fora surpreendido com condições adversas no curso de relações negociais de trato sucessivo ou diferido, passando a não comportar o pagamento das dívidas sem prejudicar o próprio sustento. Assim, ressalta-se que MartinsCosta (1999), ao tratar da interpretação com esteio nas cláusulas gerais, argumenta que o cuidado do intérprete deve, também, repousar na análise da singularidade do caso e não a substituir por um enquadramento automatizado da solução fixada no "grupo de casos", ou seja, deve haver ponderação.

A falta de lei específica não autoriza a aplicação de considerações pessoais no que tange ao superendividamento como oportunidade de se alcançar a Justiça social, desvinculando esse conceito da construção das normas privadas firmadas no seio da autonomia privada. 
Assim, não deixando de lado a proteção dos mais fracos, mas a observando como elemento de "defesa do próprio mercado e das relações econômicas baseadas em contratos" (PEREIRA, 2018, p. 99), reforçando a tutela da confiança. Não abdicando dos modelos jurídicos e dogmáticos ou hermenêuticos, mas considerando-os, projetando novos modelos decisórios através de correta interpretação, integração e aplicação das normas. Sempre levando em conta a excepcionalidade de intervenção na execução dos contratos, visando a estabilidade dos vínculos através do respeito ao pactuado, alcançando a dupla finalidade da função social do contrato: o escopo econômico e particular (imediata) e interesse social (mediata) (PEREIRA, 2018).

\section{A RELEVÂNCIA DO TRATAMENTO AO SUPERENDIVIDAMENTO COMO PROPOSTA DE RESGATE À VIDA CIVIL DO CONSUMIDOR}

O Estado Social enfatizou a proteção da parte mais frágil e reequilíbrio dos ajustes, perdendo a força do voluntarismo. Em seguida, com a centralização da Constituição no ordenamento jurídico, o Estado de Direito passou a tutelar as necessidades do cidadão consumidor fruto da dimensão humana dos direitos humanos (PEREIRA, 2018).

A relevância de tratamento, encontra na doutrina alemã a sugestão de um direito geral de denúncia dos contratos de longa duração que levarem a parte mais fraca à ruína, atualmente previsto no Código Civil alemão (BGB). Semelhantemente no direito brasileiro assevera Marques (2002, p. 80):

\footnotetext{
Poderia efetivamente ser extraído também no ordenamento jurídico brasileiro com base nos Art. 6, V e Art. 53 do CDC, de forma a evitar a morte do consumidor como homoeconorrúcus e resolver, mesmo que de forma indireta, os muitos problemas do superendividamento no país. O direito de rescindir o contrato, mesmo inadimplente, é excepcional e só pode ser concedido à parte mais fraca, o consumidor, como se retira da ratio legis do Art. 54, $\S 2^{\circ}$, do Art. 51, XI e $\S 2^{\circ}$, do Art. 52, $\S 2^{\circ}$, do Art. 53 e do Art. 6, V do CDC.
}

A Constituição ao garantir a livre iniciativa, identifica a autonomia privada como princípio da ordem econômica e social. Portanto, é instrumento de sua capacidade negocial de criar normas individuais na circunscrição de sua livre iniciativa, porém regrada aos limites constitucionais da função social do contrato, da boa-fé, do enriquecimento sem causa e da liberdade contratual. Frisa-se que, as limitações não comparecem para mitigar a autonomia 
privada, mas a prestigiam como a liberdade de ação privada das partes e não apenas a vontade individual desta (NANNI, 2004).

Quanto a função social do contrato, entende-se que o tratamento abrange o resgate da vida civil, pois a medida que o superendividado de boa-fé, que renegocia suas dívidas junto aos credores, tem a oportunidade de ter acesso ao crédito no momento oportuno e, assim, ser reinserido no mercado das relações privadas, inclusive, mas não somente, no mercado de consumo.

Nanni (2004) vai afirmar que é moderada à possibilidade de revisão dos contratos em prol da equidade dos fins sociais do contrato, posto não serem mais limitado às partes mas devendo serem adaptados às exigências do bem comum.

Outra figura de grande relevo é a boa-fé como padrão imposto pela Constituição, vista como um padrão de comportamento da autonomia privada que, na sua ausência, permite a interferência do Estado. Sendo a boa-fé objetiva, o intérprete observa o ajuste de conduta conforme a honestidade, lealdade e probidade, ou seja, o comportamento do indivíduo. Já a boa-fé subjetiva, o intérprete analisa o estado de consciência, a intenção do indivíduo (NANNI, 2004). Destacando-se, assim, a boa-fé objetiva para os casos de análise do tratamento do superendividamento.

Fenômenos como a massificação do consumo (crescimento dos contratos de adesão) favoreceram o desenvolvimento dos modelos jurídicos dogmáticos; os modelos contratuais de equivalência (modelos negociais) ocorrem em grandes negociações; o comercio eletrônico e novas formas de contratos no mercado financeiro são oriundos da atual dinâmica de novas situações jurídicas. Nesse sentido, regras e dogmas passam a ter a necessidade de serem revistos para a projeção de modelos jurídicos atuais para que a função do contrato seja mantida (PEREIRA, 2018).

Afinal, é importante frisar que fatos imprevisíveis podem inviabilizar para uma das partes a possibilidade do cumprimento parcial ou total do contrato, como ocorrido a exemplo da crise pandêmica da atualidade, podendo acarretar a condição de superendividamento, o qual traz a inquietação pelo emergir da relevância de seu tratamento. Para que o devedor de boa-fé que está em situação de superendividamento, possa encontrar um sistema de direitos e garantias no ordenamento que seja eficaz em reinserir esse consumidor no mercado.

Nesse sentido, o Projeto de Lei (PL) 3.515/2015 (que visa trazer alterações ao Código de Defesa do Consumidor - CDC), atualmente tramitando na Câmara dos Deputados, 
prevê a possibilidade de renegociação conjunta entre as partes (devedor e credor/credores), onde se uma das partes não quer renegociar, submete-se ao judiciário, desde que não haja o oportunismo excessivo do devedor superendividado (BRASIL, 2015).

Nesse sentido, a essência da fonte do direito é analisada pelos modelos jurídicos dogmáticos, assim como extraindo do conteúdo dos contratos o modelo jurídico que se coaduna na realidade social, trata-se da renovação da teoria voluntarista, onde esse trabalho cientifico quando bem desenvolvido permita preencher lacunas respeitando as estruturas de sentido parte da experiência jurídica (PEREIRA, 2018).

Entretanto, atualmente não há um tratamento positivado ao superendividamento, conforme almeja o PL 3.515/2015 (conhecido como o PL do Superendividamento o qual é voltado ao consumidor de boa-fé.), competindo aos Poderes vislumbrarem esse grupo e suas vulnerabilidades. Assim como, considerar os reflexos trazidos à sociedade e economia da nação pela ausência de tratamento e o aumento da morte civil desses indivíduos.

O endividamento crescente (CNC, 2020) ${ }^{4}$ encontra alguns motivos apontados como a redução de renda, desemprego, doença ou morte na família, por exemplo. Dados mostram, segundo o Instituto Brasileiro de Defesa do Consumidor (IDEC, 2019), que no Brasil são mais de 60 milhões de endividados, dos quais 30 milhões eram estimados antes da pandemia do Covid-19 como aqueles tem mais contas ou dividas que sua capacidade de pagamento. Porém, conforme divulgado em 10 de setembro de 2020 pelo mesmo Instituto, esse número deve aumentar para 42 milhões de superendividados, o equivalente à população da Argentina (IDEC, 2020). ${ }^{5}$

Importante perceber que, o sistema móvel se encontra entre a formação rígida de previsões normativas e a pura cláusula de equidade. Posto a razoabilidade da consideração das circunstâncias do caso concreto e do valor jurídico específico da equidade. Sendo ele um meio termo entre previsões normativas rígidas e as cláusulas gerais, com papel importante para o legislativo e para a concretização das cláusulas gerais (CANARIS, 2008).

\footnotetext{
${ }^{4}$ Conforme a Pesquisa Nacional de Endividamento e Inadimplência do Consumidor (Peic Nacional) que é apurada mensalmente pela Confederação Nacional do Comércio de Bens, Serviços e Turismo (CNC) após ter alcançado recorde histórico em agosto $(67,5 \%)$ o percentual de famílias com dívidas no País diminuiu em setembro para $67,2 \%$ do total.

5 Para o Instituto Brasileiro de Defesa do Consumidor o PL 3.515/2015, esse cenário tem como ponto importante o plano para recuperação financeira do consumidor, com planejamento para o pagamento das dívidas, preservando uma renda mínima, devolvendo dignidade às pessoas e dinheiro à economia, com as famílias voltando a consumir e a economia ativa.
} 
Nesse sentido, o sistema móvel permite considerações acerca de institutos sem lei especial ou menção expressa no ordenamento, demonstrando a unicidade e ordenamento do sistema jurídico. Dessa maneira, oportuniza tutelar o superendividamento de maneira a construir modelos jurídicos em detrimento de considerações pessoais do legislador e do interprete, subjetivismos os quais se encontram fora do ordenamento.

Desse modo, entre os benefícios do citado PL que podem vir a ser inseridos no ordenamento está a construção de modelos jurídicos respeitando a autonomia privada. Nesse viés, Pereira (2018) entende que o protagonismo do Judiciário, como agente político que é, não deve visar atuar na transformação social movidos por convicções pessoais, mas primando pelo protagonismo das partes contratantes, fomentando a autocomposição, o cumprimento dos ajustes. Mas acaso superado esses momentos pelas partes, intervindo o mínimo possível sob auxilio dos modelos dogmáticos e apenas, em última hipótese, declarar a extinção do contrato.

Ressalta-se, que o considerado evoluído modelo francês de reeducação financeira possui três ordens de tutela do consumidor de crédito: 1) limitações à concessão de crédito (com um délai de réflexion alargado, com a ligação entre o contrato principal de consumo e o contrato de crédito e com a limitação das garantias pessoais); 2) prevenção do superendividamento (através de uma base de dados nacional sobre incidentes de pagamento); 3) tratamento do superendividamento (CARVALHO, 2018).

Devendo a busca pela função social do contrato (Art. 421 do Código Civil) ser consagrada sem o abuso de uma das partes em detrimento da outra. O princípio da boa-fé objetiva apresentado pelos balizamentos de Martins-Costa (1999), nesse sentido, em contrapartida à boa-fé subjetiva, vem afirmar (MARTINS-COSTA, 1999, p. 14):

[...] na concreção da boa-fé objetiva, deve o intérprete desprender-se da pesquisa da intencionalidade da parte, de nada importando, para a sua aplicação, a sua consciência individual no sentido de não estar lesionando direito de outrem ou violando regra jurídica. O que importa é a consideração de um padrão objetivo de conduta, verificável em certo tempo, em certo meio social ou profissional e em certo momento histórico.

A tríplice crise da nossa realidade (a crise da doutrina, a crise da jurisdição e a crise da lei) agrava os riscos de legislar por cláusulas gerais e a legislar por princípios o que necessita "parcimônia do legislador na elaboração de enunciados "abertos", e prudência do aplicador que deverá efetuar uma especial e muito cuidadosa motivação da decisão" (MARTINS-COSTA, 1999, p. 27). Portanto, a ponderação das duas técnicas legislativas, ou 
seja, de cláusulas gerais (ou dos princípios) e da rigidez da norma casuística são remédios para o fim de proporcionar ao sistema, em sua interpretação e aplicação, certeza e segurança sobre as regras do tráfego jurídico (MARTINS-COSTA, 1999).

O método de legislar por cláusulas gerais (modelo da "não-casuística") é diferente de legislar por meio da técnica da casuística (regra do caso). Essa última, conforme a autora cita Engisch, seria "a configuração da hipótese legal que circunscreve particulares grupos de casos na sua especificidade própria” (MARTINS-COSTA, 1999, p. 3), portanto sem a generalidade daquela. Assim, o PL pode trazer ambas as formas, inclusive em um mesmo enunciado. Por fim, a fim de enriquecer o debate mas sem aprofundar posto que, nesse momento, não se está a analisar partes do Projeto, é importante ressaltar que os requisitos para se definir o superendividado a ser beneficiado com o resgate da vida civil devem ser o quanto mais possível de ser clarificado, posto os riscos de os indivíduos superendividados de boa-fé não serem tutelados.

\section{CONSIDERAÇÕES FINAIS}

Conforme ponderado, o Direito é parte de um contexto de dinâmica e mutações da sociedade. Portanto, a mobilidade é característica intrínseca, como ocorre no Direito Civil que, absorvendo os impactos constitucionais, viu despontar o caminho da transição ocorrida da autonomia da vontade para a autonomia privada através, também, do sistema ter encontrado novas balizas com o advento da Constituição Federal.

Assim, a releitura da norma ordinária em harmonia com os princípios fundamentais, portanto reconhecidos na Constituição, somadas às as dinâmicas do Mundo da Vida impactam diretamente na construção de novos modelos jurídicos que venham a disciplinar, tutelar e dar tratamento às novas demandas da sociedade e da ordem econômica.

Nesse sentido, é do Direito o papel de disciplinar as relações posto as características de ordem e unidade do sistema jurídico. Onde o direito civil recebe influência direta da ordem constitucional, em que em sua faceta das relações contratuais visa a construção de modelo jurídicos, em especial legislativos ao se tratar do citado PL 3515/2015 e decisórios em relação às demandas oriundas do superendividamento, em que almeja interpretação restritiva voltada à conservação do negócio entabulado pelo consumidor e credor. 
Ainda em consonância com a harmonia de normas e princípios do Direito civil constitucional, desconsiderar as relações jurídicas, as quais criam normas objetivas entre as partes contratantes, é suprimir da sociedade o exercício de inúmeros direitos fundamentais, inclusive nas relações de consumo.

O aludido Projeto de Lei, além da prevenção do superendividamento, ambiciona alcançar o consumidor superendividado de boa-fé que, consequentemente, quer desvencilharse da trajetória da morte civil para o mercado de consumo. Sua sanção é parte do reconhecimento, pelo Direito Privado Contemporâneo de que a mobilidade social e do sistema jurídico estão em consonância.

Reconhecendo, ainda, a vontade privada e como os negócios jurídicos são a exteriorização da vontade dos contratantes. Sendo, portanto, de interesses privados as partes podem, também juntas, chegarem a um consenso benéfico ao credor que poderá receber uma dívida vencida, ao devedor superendividado de boa-fé que poderá ser resgatado do caminho de exclusão social sem a perda do mínimo existencial e, a nível macroeconômico, benéfico ao mercado de consumo posto que sobrevive da circulação de bens e riquezas.

Enquanto não há a sanção e vigência de tal tratamento pela lei brasileira, devemos lembrar que o sistema jurídico é formado por cláusulas gerais e previsão normativa, encontrando-se o sistema móvel em posição intermediária entre essas. Assim, a concepção de em conjunto os contratantes (devedor e credores) construírem a renegociação, é possível como vem sendo realizados em projetos-pilotos produzindo um título extrajudicial.

Desse modo, respeita-se ao pactuado garantindo a observância da autonomia privada e os fins do contrato de circulação de bens e riquezas, importantes para o equilíbrio da economia. Sendo, portanto, reconhecida a função social do contrato e a boa-fé. Uma espécie de Recuperação, assemelhando-se à hipótese de pessoas jurídicas, mas de pessoas físicas.

Dessa maneira, devido a ordem e unicidade do sistema jurídico, abrange o resgate da vida civil à medida que o superendividado de boa-fé tem a oportunidade de ter acesso ao crédito no momento oportuno e, assim, ser reinserido no mercado das relações privadas, inclusive no mercado de consumo, alcançando, entre outros, um dos pilares do Estado de Direito na busca pela tutela de demandas do consumidor proveniente dos direitos fundamentais.

Portanto, o pensamento sistemático observando à margem da insolvência de expressivo número de devedores, mostra para a economia creditícia um sinal de alerta a não 
ser excedido, mas se for, haverá mecanismos para resgatar esse devedor antes que ele permaneça no superendividamento.

\section{REFERÊNCIAS}

BRASIL. Câmara dos Deputados. Projeto de Lei $\mathbf{n}^{\mathbf{0}}$ 3.515/2015. Altera a Lei $\mathrm{n}^{\circ}$ 8.078, de 11 de setembro de 1990 (Código de Defesa do Consumidor), e o art. 96 da Lei $\mathrm{n}^{\circ} 10.741$, de $1^{\circ}$ de outubro de 2003 (Estatuto do Idoso), para aperfeiçoar a disciplina do crédito ao consumidor e dispor sobre a prevenção e o tratamento do superendividamento. Disponível em: https://www.camara.leg.br/proposicoesWeb/fichadetramitacao?idProposicao=2052490. Acesso em: 13 out. 2020.

CANARIS, Claus-Wilhelm. Pensamento sistemático e conceito de sistema na ciência do direito. 4. ed. Lisboa: Fundação Calouste Gulbenkian, 2008.

CARVALHO, Diógenes Faria de; SILVA, Frederico Oliveira. Superendividamento e mínimo existencial: teoria do reste à vivre. Revista de Direito do Consumidor, São Paulo, v. 118, ano 27, p. 363-386, jul./ago. 2018.

\section{CONFEDERAÇÃO NACIONAL DO COMÉRCIO DE BENS, SERVIÇOS E TURISMO} (CNC). CNC registra primeira queda no endividamento dos brasileiros desde maio. 30 de setembro de 2020. Disponível em: https://www.portaldocomercio.org.br/noticias/cncregistra- primeira-queda-no-endividamento-dos-brasileiros-desde-maio/342403. Acesso em: 15 out. 2020.

FERRI, Luigi. La autonomia privada. Trad. Luís Sancho Mendizabal. Madrid: Revista de Derecho Privado, 1969.

FINGER, Cesar Julio. Constituição e direito privado: algumas notas sobre a chamada constitucionalização do direito civil. In: SARLET, Ingo Wolfang (org.). A constituição concretizada: construindo pontes com o público e o privado. Porto Alegre: Livraria do Advogado, 2000.

INSTITUTO BRASILEIRO DE DEFESA DO CONSUMIDOR (IDEC). Pressione pela aprovação do "PL do Superendividamento". 10 de julho de 2019. Disponível em: https://idec.org.br/campanha/superendividamento?utm_medium=referral\&utm_source=landin g-

superendividamento\&utm_campaign=superendividamento\&utm_content=superendividament o-repense\&utm_term=link. Acesso em: 13 out. 2020.

INSTITUTO BRASILEIRO DE DEFESA DO CONSUMIDOR (IDEC). CDC: 30 anos em defesa de todos! Revista do Idec, n. 232, set./out. 2020. Disponível em:

https://idec.org.br/revista/cdc-30-anos-em-defesa-de-todos. Acesso em: 13 out. 2020.

MARQUES, Claudia Lima. Boa-fé nos serviços bancários, financeiros de crédito e securitários e o Código de Defesa do Consumidor: informação, cooperação e renegociação? 
Revista da Faculdade de Direito da UFRGS, Porto Alegre, v. 1, n. 22, p. 47-83, 2002. https://www.seer.ufrgs.br/revfacdir/article/viewFile/72637/41109. Acesso em: 13 out. 2020.

MARQUES, Claudia Lima; LIMA, Clarissa Costa; BERTONCELLO, Káren. Prevenção e tratamento do superendividamento. Brasília: : DPDC/SDE, 2010. Disponível em: https://legado.justica.gov.br/seus-direitos/consumidor/Anexos/manual-tratamento-dosuper\%20endividamento.pd. Acesso em: 14 out. 2020.

MARTINS-COSTA, Judith. A Boa-Fé no Direito Privado: critérios para a sua aplicação. São Paulo: Revista dos Tribunais, 1999.

NANNI, Giovanni. A evolução do Direito civil obrigacional: a concepção do Direito Civil constitucional e a transição da autonomia da vontade para a autonomia privada. In: LOTUFO, Renan (coord.). Cadernos de direito civil constitucional: Caderno $n^{\circ} 2$. Curitiba: Juruá, 2004.

PEREIRA, Paulo Sérgio Velten. Contratos: tutela judicial e novos modelos decisórios. Curitiba: Juruá, 2018.

POPP, Carlyle. Princípio constitucional da dignidade da pessoa humana e a liberdade negocial - a proteção contratual no direito brasileiro. In: LOTUFO. Renan (coord.). Direito civil constitucional: Cadernos 1. São Paulo: Max Limonad, 1999. p. 151 - 211.

TEPEDINO, Gustavo. Temas de Direito civil. 3. ed. rev. atual. Rio de Janeiro: Renovar, 2004. 